\title{
Antibacterial Activity and Protective Role against Gastric Cancer by Sedum sarmentosum
}

\author{
Ji Yeon Choi $\cdot$ Hye Min Kim $\cdot$ So-Youn Mok $\cdot$ Kyung Choi $\cdot$ Jajung Ku \\ Kwang-Woo Park · Eun Ju Cho $\cdot$ Sanghyun Lee
}

\section{돌나물의 항균활성 및 위암예방효과}

최지연 · 김혜민 · 목소연 · 최경 · 구자정 · 박광우·조은주 · 이상현

Received: 30 April 2012 / Accepted: 18 June 2012 / Published Online: 30 September 2012

(C) The Korean Society for Applied Biological Chemistry 2012

\begin{abstract}
The aim of this research was to investigate the industrial application of Sedum sarmentosum. Antibacterial activities of the $n$-hexane, methylene chloride (MC), ethyl acetate, and $n$-butanol fractions of S. sarmentosum were tested against Escherichia coli, Staphylococcus aureus, and Helicobacter pylori. The MC fraction showed the strongest antibacterial activity against $E$. coli, with an inhibition zone greater than $13 \mathrm{~mm}$ in disc assays. At $100 \mu \mathrm{g} / \mathrm{mL}$, all fractions scavenged more than $50 \%$ of 1,1-diphenyl-2picrylhydrazyl (DPPH) and hydroxyl radicals $(\cdot \mathrm{OH})$. In particular, the $\mathrm{MC}$ fraction showed the strongest scavenging activity against $\mathrm{DPPH}$ and $\cdot \mathrm{OH}$. In addition, we found that treatment with the MC fraction inhibited the growth of $H$. pylori and gastric adenocarcinoma cells. The present results suggest that the MC fraction of $S$. sarmentosum would play the promising protective role against pathogenic bacteria and free radicals.
\end{abstract}

Keywords antibacterial $\cdot$ anticancer $\cdot$ antioxidant $\cdot$ free radical $\cdot$ Sedum sarmentosum

J. Y. Choi · E. J. Cho $(\bowtie)$

Department of Food Science and Nutrition, Pusan National University, Busan 609-735, Republic of Korea

E-mail: ejcho@pusan.ac.kr

H. M. Kim · S.-Y. Mok $\cdot$ S. Lee $(\bowtie)$

Department of Integrative Plant Science, Chung-Ang University, Anseong 456-756, Republic of Korea

E-mail: slee@cau.ac.kr

K. Choi $\cdot$ J. Ku $\cdot$ K.-W. Park

Department of Forest Resource Conservation, Korea National Arboretum, Pocheon 487-821, Republic of Korea

\section{서 론}

의학기술의 발달로 평균 수명이 연장되어 인구가 노령화된 반 면, 식습관의 변화와 운동부족으로 각종 암, 고혈압 등 순환기 계질환과 당뇨병, 간장 장애 등 만성 퇴행성 질환이 급증하고 있다(NSOK, 2011). 이에 따라 여러 측면에서 노화억제와 건강 유지를 위한 생리활성 물질에 대한 연구가 미생물과 식물분야 에서 광범위하게 연구되고 있다(Goldberg, 1994; Sadaki, 1996). 특히 $\mathrm{H}_{2} \mathrm{O}_{2}$ 등의 활성산소가 만성 퇴행성질환의 주요 위험인자 로 대두되어 이들의 제거에 대한 관심이 높아지고 있다 (Fridorich, 1978). 활성산소는 강한 산화력이 있어 세포막 분해, 단백질 분해, 지방 산화, DNA 합성 억제, 광합성 억제, 엽록체 의 파괴 등 생체 내에서 심각한 생리적인 장애를 유발한다 (Imlay and Linn, 1988; Gardner and Fridovich, 1991). 생체 내의 대사 활동이나 스트레스, 염증 등에 의한 활성 산소의 과 잉 생성은 인체의 효소 및 단백질, DNA 등의 손상을 가져오 고 현재까지의 다양한 연구에 의하면 이러한 과잉 공급된 활성 산소로 인해 유전자를 손상시키는 암의 개시 단계뿐만 아니라 촉진 단계에서도 작용하여 발암의 원인이 되는 것으로 알려져 있다(Jung 등, 2006).

우리나라 식중독 발생의 경우 주 원인균으로 살모넬라균이나 포도상구균, 대장균 등을 들 수 있는데(Bae, 2005), 이와 같은 식중독 유발세균에 대한 천연 식물의 항균 효과를 과학적으로 검증하고자 하는 연구가 활발히 진행 중이다(Lee 등, 2011). 또 한 헬리코박터(Helicobacter pylori)는 위염, 위궤양 및 위암의 발병요인으로서 1983년 보고된 후 지난 20여 년간 주목을 받 기 시작한 균으로 (Waren and Marshall, 1983) 현재까지도 이 에 관한 역학 및 병인에 관한 많은 연구가 이루어지고 있다. 이 균은 그람음성의 미호기성균으로 강한 운동성을 갖고 있으며 위 점막과 점액의 강한 산성환경에서 서식하면서 위점막에 $H$. pylori urease에 의해 암모니아를 축적함으로써 직접 또는 간접 
적으로 위점막의 손상을 초래하여 위염이나 위궤양을 유발시키 는 것으로 알려져 있다(Graham, 1989). 현재까지 이 세균을 제 거하기 위한 여러 항생제가 개발(Ohta 등, 2001; Parente 등, 2002; Isomoto 등, 2003)되어 왔으나, 항생제를 장기간 투여하 는 것에 따른 항생제 내성을 갖는 새로운 균주가 나타나고 사 용한 약물에 의한 부작용이 있을 수 있기 때문에 다른 접근 방 식이 요구되고 있는 실정이다(Yoon 등, 2011).

석상채(石上採), 불갑초(佛甲草), 석련화(石蓮花) 또는 수분초 (垂盆草)라고 불리는 돌나물(Sedum sarmentosum)은 돌나물과에 속하는 다년생 다육식물로 전국 산야지에 분포하고 있는 산채 식품으로, 돈나물, 돋나물, 수분초(垂盆草), 구아치(拘牙齒), 삼엽 불갑초(三葉佛甲草)라고도 한다(Kwack, 1976). 외관은 두터운 타원형의 잎이 줄기의 마디를 따라 3장씩 윤생하며, 5-6월경에 노란색의 별모양의 꽃이 피는데, 이는 관상가치가 높아 약용, 식 용뿐만 아니라 관상용으로 쓰인다. 특히 내한성 및 내건성이 강 하여 토질을 가리지 않고 자라는 생육특징을 지니고 있어 우리 나라 어디에서나 손쉽게 재배할 수 있다. 돌나물은 sedoheptulose, sucrose, fructose 등의 당질과, 특히 비타민 $\mathrm{C}$ 와 칼슘의 함량이 높은 것으로 보고되었으며, 최근 자생식물의 중요성이 부각되면 서 돌나물의 유용성분탐색과 함께 다양한 생리활성 능력이 입 증되고 있다(Kim and Lee, 2007; Sim 등, 2008). 돌나물의 활 성성분 연구로는 quercetin, isorhamnetin과 kaempferol 등의 배 당체들에 의한 angiotensin converting enzyme 저해효과와, terpenoids에 의한 간보호 효과 등이 있다(He 등, 1998; Oh 등, 2004). 또한 돌나물 추출물이 각질형성 세포에서의 hyaluronan 생성 촉진 작용이 있다는 것이 보고 되었으며, 또한 활성산소 소거활성 및 멜라닌생성 저해 효과가 보고되었다(Sim 등, 2007; 2008). 그리고 돌나물의 alkaloid 분획물이 murine hepatoma와 human hepatoma에 대해 항증식 효능이 있음이 보고되었다 (Kang 등, 2000). 그리고 민간에서는 돌나물의 뿌리와 잎이 대 하증, 선혈 등의 약제로 쓰이고 달여서 즙을 마시면 해열, 염증, 해독에 좋으며 인후두염, 만성간염, 사교창, 화상에도 쓰인다고 한다 $(\mathrm{Kim}$ 등, 2002). 그러나 돌나물의 이러한 생리활성을 뒷받 침할 수 있는 과학적 연구결과는 미흡한 실정이다.

따라서 본 연구에서는 기능성식품 또는 의약품 중간원료로의 용도 개발을 위한 기초연구의 일환으로 돌나물이 가지는 우수한 가치를 알고 이를 활용하기 위해 1,1-diphenyl-2-picrylhydrazyl $(\mathrm{DPPH})$ 소거능과 hydroxyl radical $(\cdot \mathrm{OH})$ 소거능 측정을 통해 항산화 효과를 검색해 보고, 식중독 유발 세균인 Escherichia coli (E. coli)와 Staphylococcus aureus (S. aureus)에 대한 항 균효과와 위암세포주인 $\mathrm{AGS}$ 에 대한 생육저해 효과 및 $H$. pylori에 대한 항균활성을 탐색하여 천연항산화제로서의 소재와 천연항균제재, 위암의 예방에 효과적인 고부가가치의 생리 기능 을 갖는 천연의 기능성 소재로의 활용하기 위한 자료를 얻고자 검토하였다.

\section{재료 및 방법}

실험재료. 식물재료로 사용된 돌나물(S. sarmentosum)은 2010년 광릉에서 채집된 것을 국립수목원으로부터 제공받았다.

추출물 및 분획물의 조제방법. 음건을 통해 준비된 돌나물은 모 두 $3.0 \mathrm{~g}$ 을 정량하며 분쇄하여 추출에 사용하였다. 추출방법은 온침(heating method)을 이용하였으며, 메탄올(methanol)을 사용
하여 추출하였다. 사용된 메탄올 용매는 $300 \mathrm{~mL}$ 를 사용하였으 며, 이를 세 시간 동안 3 반복으로 실시하여 추출하였다. 추출액 은 여과지를 이용하여 여과한 후 감압농축을 사용하여 메탄올 추출물(methanol extract)을 얻었다. 얻어진 메탄올 추출물을 물 에 현탁하여 극성이 다른 네 가지 유기용매 $n$-hexane, methylene chloride (MC), ethyl acetate (EtOAc), n-butanol $(n-\mathrm{BuOH})$ 로 각각 분획하여 분획물을 얻었다.

DPPH 소거능 측정. 시료 $100 \mu \mathrm{L}$ 와 $60 \mu \mathrm{M} \mathrm{DPPH}$ 용액 $100 \mu \mathrm{L}$ 를 96 well plate에 혼합하여 30분간 실온에 방치시킨 후, $540 \mathrm{~nm}$ 에서 흡광도를 측정하였다. 시료를 첨가하지 않은 대조 군과 비교한 $\mathrm{DPPH}$ 소거효과를 백분율 $(\%)$ 로 나타내었다(Hatano 등, 1989).

Hydroxyl radical (·OH) 소거능 측정. Fenton 반응에 따라 $10 \mathrm{mM} \mathrm{FeSO}{ }_{4} \cdot \mathrm{H}_{2} \mathrm{O}$-EDTA에 $10 \mathrm{mM}$ 의 2-deoxyribose solution 과 시료를 $100 \mu \mathrm{g} / \mathrm{mL}$ 농도로 처리한 후, $10 \mathrm{mM}$ 의 $\mathrm{H}_{2} \mathrm{O}_{2}$ 를 첨 가하여 $37^{\circ} \mathrm{C}$ 에서 4 시간 동안 배양하였다. 이 혼합액에 $2.8 \%$ trichloroacetic acid와 $1.0 \%$ thiobarbituric acid solution을 각각 첨가하여 20 분간 끓여 식힌 후 $490 \mathrm{~nm}$ 에서 흡광도를 측정하였 다(Chung 등, 1997).

일반세균 배양. 실험에 사용한 그람 양성균 $S$. aureus와 그람 음성균 E. coli는 한국미생물보존센터(KCCM, Korea)에서 분양 받아 사용하였다. S. aureus는 nutrient 배지(beef extract $30 \mathrm{~g}$, peptone $50 \mathrm{~g}$, 증류수 $1 \mathrm{~L}$ )를, E. coli는 luria-bertani 배지(LB 배지, Bacto tryptone $10 \mathrm{~g}$, yeast extract $5 \mathrm{~g}, \mathrm{NaCl} 50 \mathrm{~g}$, 증 류수 $1 \mathrm{~L}$ )를 조제하여 사용하고, $37^{\circ} \mathrm{C}$ incubator에서 배양하였다. H. pylori 배양. 실험에 사용한 균주는 위 및 십이지장 궤양 원 인균인 H. pylori strain 26695로 헬리코박터 파이로리 분리 균주 은행에서 분양받아 사용하였다. 균의 배양에는 $10 \%$ horse serum (Welgene, Korea)을 첨가한 Brucella broth (Difco, USA)를 이용 하였으며, 배지의 조성은 Bacto tryptone $10 \mathrm{~g}$, Bacto peptamin $10 \mathrm{~g}$, Bacto dextrose $1 \mathrm{~g}$, Bacto yeast extract $2 \mathrm{~g}$, sodium chloride $5 \mathrm{~g}$, sodium bisulfite $0.1 \mathrm{~g}$ 으로 구성되어 있다. 미호기 성 조건을 유지시켜 주기 위해서 $\mathrm{CO}_{2}$ incubator는 $10 \% \mathrm{CO}_{2}$, 습도는 항상 $95 \%$ 이상으로 유지하였으며, 온도는 $37^{\circ} \mathrm{C}$ 를 유지 하였다.

항균 활성 분석. 디스크 확산법으로 $E$. coli, S. aureus 그리고 H. pylori에 대한 항균활성을 측정하였다. Brucella agar 배지에 H. pylori 균액 $100 \mu \mathrm{L}$ 를 분주하여 멸균 유리봉으로 도말한 다 음, 멸균된 disc paper ( $\varphi 8 \mathrm{~mm}$, Advantec, Japan)를 올리고 50 $\mu \mathrm{g} / 30 \mu \mathrm{L}$ 농도의 시료 $30 \mu \mathrm{L}$ 를 disc paper에 흡수시킨 후, $37^{\circ} \mathrm{C}$ 의 $\mathrm{CO}_{2}$ incubator에서 24 시간 동안 배양한 다음, 디스크 주위의 생육 저해환(clear zone) 생성 유무를 확인하였다 (Davidson and Parish, 1989).

세포 배양. AGS 인체 위암 세포(AGS, human gastric adenocarcinoma cell)는 한국 세포주은행(서울의대)에서 분양받 아 사용하였다. AGS 인체 위암 세포는 $100 \mathrm{U} / \mathrm{mL}$ 의 penicillinstreptomycin (Welgene)과 $10 \%$ fetal bovine serum (Welgene) 이 첨가된 RPMI-1640 배지(Welgene)를 이용하여 $37^{\circ} \mathrm{C}, 5 \%$ $\mathrm{CO}_{2}$ incubator에서 배양하였다. 배양된 세포는 일주일에 2-3회 refeeding하고 세포가 confluence 상태가 되면 phosphate buffered saline으로 세척한 후 $0.05 \%$ trypsin- $0.02 \%$ EDTA (Welgene)로 분리하여 원심분리한 후 집적된 세포에 배지를 넣고 세포가 골 고루 분산되도록 잘 혼합하여 계대 배양하면서 실험에 사용하 였다. 
세포 증식 저해효과 측정. 세포 증식 저해율은 3-(4,5dimethylthiazol-2-yl)-2,5-diphenyl tetrazolium bromide (MTT) assay를 이용하여 측정하였다. MTT assay는 세포 내 미토콘드 리아 외막의 탈수소효소작용에 의하여 노란색 수용성의 MTT tetrazolium이 자주색을 띠는 비수용성의 MTT formazan으로 환 원되는 원리를 이용한 것으로 흡광도는 $540 \mathrm{~nm}$ 의 파장에서 최 대가 되며, 이 파장에서 측정된 흡광도는 대사가 왕성한 살아 있는 세포의 농도를 반영한다. 이 방법은 비교적 간편하고 객 관적 결과를 쉽게 정량화할 수 있어 암 기초 연구에서 널리 이 용되는 방법 중의 하나이다. 24 well plate에 $5 \times 10^{4}$ cells/well 로 seeding하여 세포를 부착시킨 후 시료를 $100 \mu \mathrm{g} / \mathrm{mL}$ 농도로 처리하여 24시간 배양한 뒤 $5 \mathrm{mg} / \mathrm{mL}$ 의 MTT solution을 각 well에 주입하여 $37^{\circ} \mathrm{C}$ incubator 내에서 재배양한 후 생성된 formazan을 dimethyl sulfoxide에 녹인 다음 $540 \mathrm{~nm}$ 에서 흡광도 를 측정하였다(Carmichael 등, 1987).

Inhibition rate $(\%)$

$=(1-$ 시료 처리구의 흡광도/대조구의 흡광도 $) \times 100$

통계 분석. 각 실험 결과는 평균 \pm 표준편차로 나타냈고, SAS software (SAS Institute, USA)를 이용하여 각 실험결과의 ANOVA (analysis of variance)를 구한 후 Duncan's multiple test로 각 군의 평균간 유의성을 검정하였다.

\section{결과 및 고찰}

DPPH radical은 시료의 free radical 소거 능력이나 수소 공여 능력을 평가하는 방법으로서 안정적이고 간단하며 재현성이 높 아 널리 사용되는 radical 소거능 측정방법으로 알려져 있다 (Hong 등, 2010). DPPH는 생체 내에 존재하는 radical은 아니 지만 그 자체가 홀수 전자를 갖고 있어 $517 \mathrm{~nm}$ 에서 강한 흡광 도를 나타낸다. 따라서 항산화능이 있는 물질과 반응하게 되면 안정한 complex로 전환되면서 고유의 짙은 자색이 탈색되어 흡 광도 값이 감소한다( $\mathrm{Kim}$ 등, 2010). $\cdot \mathrm{OH}$ radical은 활성산소종 으로 reactive oxygen species (ROS) 중에서 가장 독성이 강하 고 반응성이 높으며 지질산화와 많은 생리적 손상, 특히 DNA 변이를 일으켜 많은 질병의 원인이 된다. 또한 $\cdot \mathrm{OH}$ 는 $\mathrm{H}_{2} \mathrm{O}_{2}$ 로 부터 Fenton 반응에 의해 생성되며 활성산소종인 $\mathrm{ONOO}^{-}$의 분 해에 의해 생성된다(Chung 등, 1997; Kim 등, 2009).

돌나물의 $n$-hexane, MC, EtOAc, $n$ - BuOH 분획물을 $100 \mu \mathrm{g} /$ $\mathrm{mL}$ 농도로 처리 시 $\mathrm{DPPH}$ 와 $\mathrm{OH}$ 에 대한 소거능을 Table 1에 나타내었다. 네 가지 분획물 중 $\mathrm{MC}, \mathrm{EtOAc}, n-\mathrm{BuOH}$ 분획물 에서 $\mathrm{DPPH}$ 소거능이 $80 \%$ 이상으로 나타났다. 특히 EtOAc 분 획물이 $93.52 \%$ 로 가장 우수한 $\mathrm{DPPH}$ 소거능을 보였다. $\cdot \mathrm{OH}$ 소 거능을 측정한 결과, 네 분획물 모두 $80 \%$ 이상의 높은 $\cdot \mathrm{OH}$ 소 거 효과를 보였다. 특히 $n$-hexane과 $\mathrm{MC}$ 분획물은 각각 102.07 , $102.23 \%$ 로 $\mathrm{OH}$ 에 대한 독성 제거 효과가 매우 우수함을 알 수 있었다. 분획물 중에서 $\mathrm{MC}$ 분획물이 $\mathrm{DPPH}$ 와 $\cdot \mathrm{OH}$ 소거능이 모두 우수하여 in vitro에서 free radical 소거에 의한 항산화 효 과가 가장 뛰어난 것으로 생각된다.

식중독 세균으로는 식품에서 많은 문제가 되고 있는 식중독 유발 세균 중 gram 양성세균인 S. aureus와 gram 음성세균인 E. coli로 항균 효과를 살펴보기 위하여, 돌나물의 $n$-hexane, $\mathrm{MC}, \mathrm{EtOAc}, n-\mathrm{BuOH}$ 분획물을 각각 $50 \mu \mathrm{g} / 30 \mu \mathrm{L}$ 의 농도로 24
Table 1 Radical scavenging activities of the solvent fr. from $S$. sarmentosum

\begin{tabular}{lcc}
\hline \multirow{2}{*}{$\begin{array}{c}\text { Sample } \\
(100 \mu \mathrm{g} / \mathrm{mL})\end{array}$} & \multicolumn{2}{c}{ Scavenging activity $(\%)$} \\
\cline { 2 - 3 }$n$-Hexane fr. & $51.22 \pm 0.45^{\mathrm{d}}$ & $102.07 \pm 0.21^{\mathrm{a}}$ \\
MC fr. & $81.07 \pm 0.29^{\mathrm{c}}$ & $102.23 \pm 0.90^{\mathrm{a}}$ \\
EtOAc fr. & $93.52 \pm 0.19^{\mathrm{a}}$ & $87.12 \pm 0.14^{\mathrm{c}}$ \\
$n$-BuOH fr. & $89.94 \pm 0.16^{\mathrm{b}}$ & $88.60 \pm 0.10^{\mathrm{b}}$ \\
\hline
\end{tabular}

${ }^{\mathrm{a}-\mathrm{d}}$ Means among fractions with the different letters are significantly different $(p<0.05)$ by Duncan's multiple range test.

Table 2 Antibacterial activities of the solvent fr. from $S$. sarmentosum

\begin{tabular}{lccc}
\hline Sample & \multicolumn{3}{c}{ Clear zone $(\mathrm{mm})$} \\
\cline { 2 - 4 }$(50 \mu \mathrm{g} / 30 \mu \mathrm{L})$ & E. coli & S. aureus & H. pylori \\
\hline$n$-Hexane fr. & 8 & 12 & 8 \\
MC fr. & 13 & 8 & 8 \\
EtOAc fr. & 8 & 8 & 8 \\
$n$-BuOH fr. & 10 & 8 & 8 \\
\hline
\end{tabular}

Table 3 Cell growth inhibition in human AGS cells by the solvent fr. from $S$. sarmentosum

\begin{tabular}{cc}
\hline Sample $(100 \mu \mathrm{g} / \mathrm{mL})$ & Growth Inhibition $(\%)$ \\
\hline$n$-Hexane fr. & $4.97 \pm 0.95^{\mathrm{b}}$ \\
MC fr. & $48.83 \pm 0.83^{\mathrm{a}}$ \\
EtOAc fr. & $1.69 \pm 0.75^{\mathrm{c}}$ \\
$n$-BuOH fr. & - \\
\hline
\end{tabular}

${ }^{a-c}$ Means among fractions with the different letters are significantly different $(p<0.05)$ by Duncan's multiple range test.

시간 동안 처리하여, E. coli와 S. aureus의 생육 억제환을 측정 하였다. E. coli는 이에 의해 오염된 식품 섭취에 따른 식중독 발생이 전 세계적으로 증가하여 우리나라에서도 제 1 군 전염병 으로 지정된 주요한 병원체 중의 하나이다(Lim 등, 2008). $E$. coli의 주된 감염원은 소고기, 돼지고기 등의 육류와 요구르트, 마요네즈 및 사과주스 등 다양한 식품 및 물을 통해 사람에게 감염되며 사람에서 사람으로의 전이가 가능한 것으로 보고되고 있다(Doyle, 1991; Novello, 1999). 이와 같은 E. coli는 10$100 \mathrm{CFU} / \mathrm{mL}$ 의 균량만으로 감염될 수 있고, 감염되면 Shigella dysenteriae type 1이 생산하는 shiga 독소와 동일하거나 유사한 독소를 만들어 내어 혈관 내피세포를 손상시켜 용혈성 요독증 증후군(hemolytic uremic syndrome, HUS), 혈전성 혈소판감소 성자반병(thrombotic thrombocytopenic purpura, TTP), 출혈성 대장염, 설사 및 발작 등을 유발하며 계속 진행되어 사망에 이 르기도 한다(Morrison 등, 1986; Park 등, 2008).

국내에서는 E. coli로 인한 대규모의 발병 사례는 없으나 최 근에 지속적으로 발병 사례가 보고되고 있는 추세이다(Lim 등, 2008). E. coli에 대한 생육 억제환 측정 결과, $n-\mathrm{BuOH}, \mathrm{MC}$ 분획물이 각각 10 와 $13 \mathrm{~mm}$ 의 생육 억제환을 나타내어 E. coli 에 대한 항균활성을 보였다. S. aureus는 자연 환경에 대한 저 항성이 강하기 때문에 자연계에 광범위하게 분포하고 있으며 사 람이나 동물의 화농성 병소에 존재할 뿐만 아니라 건강한 사람 과 동물의 피부 등에도 상재하고 있어 식품과 인체에 오염될 가능성이 매우 높다. 최근 환경의 변화와 외식산업의 발달로 식 
중독이 증가하고 그 종류도 다양해지고 있으며 우리나라 식중 독 발생 중에 황색포도상구균에 의한 식중독은 최근 몇 년간 가장 중요한 발생 원인이 되고 있다(Cho 등, 2011). 돌나물 분 획물 중 $n$-hexane 분획물이 S. aureus에 대한 항균활성을 나타 내 $12 \mathrm{~mm}$ 의 생육 억제환을 보였다. 위염 및 위궤양의 원인균 인 H. pylori에 대한 항균활성을 검토한 결과, 돌나물 분획물은 H. pylori에 대한 항균활성은 보이지 않았다(Table 2).

인체 위암세포 증식 억제 효과를 AGS 인체 위암세포를 이 용하여 MTT assay로 알아보았다(Table 3). MTT는 살아있는 세포에서 물에 녹지 않는 formazan crystal로 환원되는데 이 crystal을 나중에 DMSO로 녹여 생성된 흡광도로 측정하는 방 법으로 암 기초 연구에서 널리 이용되는 방법 중의 하나이다. Table 3은 돌나물의 $n$-hexane, Mc, EtOAc 세 가지 분획물에 대하여 $\mathrm{AGS}$ 인체 위암세포 생존 억제 효과를 확인한 결과이 다. 세 분획물을 $100 \mu \mathrm{g} / \mathrm{mL}$ 농도로 처리한 결과, $\mathrm{MC}$ 의 경우에 서 $48.83 \%$ 의 AGS 세포 생존 억제 효과를 확인할 수 있었다.

이상의 결과를 통해 돌나물이 radical 소거능, 식중독 유발 세 균에 대한 항균성, $\mathrm{AGS}$ 인체 위암세포 생존 저해효과에 우수 한 효과를 나타냄을 알 수 있었다. 돌나물에 관한 연구보고로 는 돌나물 성분에 관한 조사와 돌나물과에 속하는 홍경천이 노 화억제효과, 항돌연변이효과, 피로회복작용 및 활력증강작용이 있는 것으로 알려져 있다(Kim 등, 2002). 또한 돌나물은 영양 성분에 있어서 비타민 $\mathrm{C}$, 철분 및 칼슘을 많이 함유하고 있어, 골다공증에 효과가 있는 것으로 알려져 있다(Ham 등, 1998; Nam 등, 1998). 돌나물(S. sarmentosum)은 우수한 항균 및 위 암세포 예방을 비롯한 생리활성을 보유하고 있는 식물로, 본 연 구 결과를 통해 앞으로 건강 기능성 식품 및 의약품의 소재로 개발될 가능성이 높으며, 다양한 산업적 활용이 기대될 것으로 생각된다.

\section{초 록}

본 연구에서는 돌나물 분획물의 항산화 및 위암예방 효과를 다 양한 균들과 위암세포주를 이용하여 검토하였다. Escherichia coli, Staphylococcus aureus 그리고 helicobacter pylori에 대한 돌나물의 $n$-hexane, methylene chloride (MC), ethyl acetate, $n$-butanol 분획물의 항균효과를 disc 확산법으로 알아본 결과, $\mathrm{MC}$ 분획물이 E. coli에 대해 $13 \mathrm{~mm}$ 의 억제존을 보여 가장 우 수한 항균효과를 나타내는 것을 알 수 있었다. $100 \mu \mathrm{g} / \mathrm{mL}$ 농 도에서 모든 분획물은 1,1-diphenyl-2-picrylhydrazyl (DPPH)와 hydroxyl radicals $(\cdot \mathrm{OH})$ 에서 $50 \%$ 이상의 소거능을 나타냈다. 특히, $\mathrm{MC}$ 분획물이 $\mathrm{DPPH}$ 와 $\cdot \mathrm{OH}$ 에서 가장 높은 소거능을 보 였다. 또한 $\mathrm{MC}$ 분획물은 H. pylori와 위암세포의 성장을 억제 하는 것을 확인할 수 있었다. 그러므로 돌나물의 분획물 중 특 히 $\mathrm{MC}$ 분획물이 radical 소거능, H. pylori에 대한 항균성 및 $\mathrm{AGS}$ 인체 위암세포 생존 저해효과가 우수한 활성물질을 함유 하고 있을 것으로 생각된다.

\section{Keywords 돌나물 - 항균 - 항암 - 항산화 - free radical}

감사의 글 본 연구는 2011 년도 국립수목원의 민속식물자원을 활용한 유용 물질 탐색 및 이용(KNA1-2-13, 11-5)과제의 지원을 받아 수행한 것임.

\section{참고문헌}

Bae JH (2005) Antimicrobial effect of Hedyotis diffusa extracts on food-borne pathogens. J Korean Soc Food Sci Nutr 34, 107-12.

Carmichael J, DeGraff WG, Gazdar AF, Minna JD, and Mitchell JB (1987) Evaluation of a tetrazolium-based semiautomated colorimetric assay: assessment of chemosensitivity testing. Cancer Res 47, 936-42.

Cho YS, Lee J, Lee MK, Shin DB, Kim DH, and Park KM (2011) Prevalence and characterization of Staphylococcus aureus pathogenic factors isolated from various foods in Korea. Korean J Food Sci Technol 43, $648-54$.

Chung SK, Osawa T, and Kawakishi S (1997) Hydroxyl radical-scavenging effects of spices and scavengers from brown mustard (Brassica nigra). Biosci Biotechnol Biochem 61, 118-23.

Davidson PH and Parish ME (1989) Methods for testing the efficacy of food antimicrobials. Food Technol 43, 148-52.

Doyle MP (1991) Escherichia coli O157: H7 and its significance in foods. Int $J$ Food Microb 12, 289-301.

Fridorich I (1978) The biology of oxygen radicals. Science 201, 875-80.

Gardner PR and Fridovich I (1991) Superoxide sensitivity of the Escherichia coli 6-phosphogluconate dehydratase. J Biol Chem 266, 1478-83.

Goldberg I (1994) In Functional Foods: Designer Foods, Pharmafoods, Nutraceuticals. Chapman \& Hall Press, USA.

Graham DY (1989) Campylobacter pylori and peptic ulcer disease. Gastroenterol 96, 615- 25.

Ham SH, Lee SY, Choi M, and Hwang Bo HJ (1998) Antimutagenicity and cytotoxicity effects of Woorimil wheat flour extracts added with wild herb and seaweed power. J Korean Soc Food Sci Nutr 27, 1177- 82.

Hatano T, Edamatsu R, Hiramatsu M, Mori A, Fujita Y, Yasuhara T et al. (1989) Effects of the interaction of tannins with co-existing substances, VI: Effects of tannins and related polyphenols on superoxide anion radical, and on 1,1-diphenyl-2-picrylhydrazyl radical. Chem Pharm Bull 37, 2016-21.

He A, Wang M, Hao H, Zhang D, and Lee KH (1998) Hepatoprotective triterpenes from Sedum sarmentosum. Phytochemistry 49, 2607-10.

Hong J, Wie M, Leem D, Park KS, Yoon T, No KM et al. (2010) Evaluation of antioxidants activity through the chemical assay. J Biomed Res 11, 18.

Imlay JA and Linn S (1988) DNA damage and oxygen radical toxicity. Science 240, 1302-9.

Isomoto $\mathrm{H}$, Inoue $\mathrm{K}$, Furusu $\mathrm{H}$, Nishiyama $\mathrm{H}$, Shikuwa $\mathrm{S}$, Omagari $\mathrm{K}$ et al. (2003) Lafutidine, a novel histamine $\mathrm{H}_{2}$-receptor antagonist, vs lansoprazole in combination with amoxicillin and clarithromycin for eradication of Helicobacter pylori. Helicobacter 8, 111-9.

Jung HJ, Choi YJ, Won CW, and Seo YR (2006) The chemopreventive effects of antioxidant enzyme. Environ Mutagen Carcinogen 6, 35-64.

Kang TH, Pae HO, Yoo JC, Kim NY, Kim YC, Ko GI et al. (2000) Antiproliferative effects of alkaloids from Sedum sarmentosum on murine and human hepatoma cell lines. J Ethnopharmacol 70, 177-82.

Kim HJ and Lee SY (2007) Genetic relationships based on morphological characteristics in Korean native Sedum sarmentosum. Korean J Hort Sci Technol 25, 103-9.

Kim JH, Sung NY, Kwon SK, Jung PM, Choi JI, Yoon YH et al. (2010) Antioxidant activity of Stevia leaf extracts prepared by various extraction methods. J Korean Soc Food Sci Nutr 39, 313-8.

Kim WH, Bae SJ, and Kim M (2002) The effects of Sedum sarmentosum Bunge on serum lipid concentration in ovariectomized rats. $J$ Korean Soc Food Sci Nutr 31, 290-4.

Kim YD, Mahinda S, Koh KS, Jeon YJ, and Kim SH (2009) Reactive oxygen species scavenging activity of Jeju native citrus peel during maturation. $J$ Korean Soc Food Sci Nutr 38, 462-9.

Kwack BH (1976) On the ecology of Sedum sarmentosum Bunge in Korea. $J$ Korean Soc Hort Sci 17, 69-77.

Lee HJ, Lim GN, Park MA, and Park SN (2011) Antibacterial and antioxidative activity of Lespedeza cuneata G. Don extracts. Korean J 
Microbiol Biotechnol 39, 63-9.

Lim JS, Yoon JH, Min BK, and Hong WK (2008) Detection and identification of shiga-like toxin producing E. coli O157: H7 by multiplex PCR. Food Eng Prog 12, 8-14.

Morrison DM, Tyrrell DL, and Jewell LD (1986) Colonic biopsy in verotoxin-induced hemorrhagic colitis and thrombotic thrombocyropenic purpura (TTP). Am J Clin Pathol 86, 108-12.

Nam SM, Ham SS, Oh DH, Kang IJ, Lee SY, and Chung CK (1998) Effects of Artemisia iwayomogi Kitamura ethanol extract on lowering serum and liver lipids in rats. J Korean Soc Food Sci Nutr 27, 338-43.

Novello A (1999) Outbreak of Escherichia coli O157: H7 and Campylobacter among attendees of the Washington County Fair-New York, 1999. MMWR Morb Mortal Wkly Rep 48, 803-5.

NSOK (2011) Annual report on the cause of death statistics. National Statistical Office of Korea, Korea.

Oh H, Kang DG, Kwon JW, Kwon TO, Lee SY, Lee DB et al. (2004) Isolation of angiotensin converting enzyme (ACE) inhibitory flavonoids from Sedum sarmentosum. Biol Pharm Bull 27, 2035-7.

Ohta T, Shibata H, Kawamori T, Iimuro M, Sugimura T, and Wakabayashi K (2001) Marked reduction of Helicobacter pylori-induced gastritis by urease inhibitors, acetohydroxamic acid and flurofamide, in Mongolian gerbils. Biochem Biophys Res Commun 285, 728-33.
Parente F, Sainaghi M, Sangaletti O, Imbesi V, Maconi G, Anderloni A et al. (2002) Different effects of short-term omeprazole, lansoprazole or pantoprazole on the accuracy of the ${ }^{13} \mathrm{C}$-urea breath test. Aliment Pharmacol Ther 16, 553-7.

Park S, Kim H, Paek SH, Hong JW, and Kim YK (2008) Enzyme-linked immune-strip biosensor to detect Escherichia coli O157:H7. Ultramicrorscopy 108, 1349-51.

Sadaki O (1996) The development of functional foods and materials. Bioindustry 13, 44-50.

Sim GS, Kim JH, Lee BC, Lee DH, Lee GS, and Pyo HB (2008) Inhibitory Effects on Melanin Production in B16 Melanoma Cells of Sedum sarmentosum. Arch Pharm Res 52, 165-71.

Sim GS, Kim JH, Lee DH, Na Y, Lee GS, and Pyo HB (2007) Sedum sarmentosum enhances hyaluronan synthesis in transformed human keratinocytes and increases water content in human skin. $J$ Soc Cosmet Scientists Korea 33, 17-22.

Waren JR and Marshall B (1983) Unidentified curved bacilli on gastric epithelium in active chronic gastritis. Lancet 321, 1273-5.

Yoon SJ, Kim JS, Jo BS, Kim JH, Lee SH, Ahn BJ et al. (2011) Isolation and identification of antimicrobial compounds against Helicobacter pylori from Rosemary (Rosmarinus officinalis L.) extracts. J Appl Biol Chem 54, 159-65. 